\title{
Emerson Hough's American West
}

\section{CAROLE M. J OH N S N}

In 1938 Wallace Stegner wrote an article, "The Trail of the Hawkeye: Literature Where the Tall Corn Grows," commemorating the hundredth anniversary of the formation of Iowa Territory. ${ }^{1}$ Although he acknowledged that Emerson Hough was the earliest Iowa author of any fame, Stegner dismissed his significance as a writer because Hough's work fit no pattern and left no "recognizable legacies to authors of his state and region except his keen interest in the western migrations of settlers." ${ }^{2}$ Recent studies indicate that this statement needs modification. ${ }^{3}$ Indeed, Hough ranged far beyond Iowa in his travels and interests, achieving a national rather than a regional prominence. Traveler, historian, novelist, journalist, and conservationist, he wrote more than thirty-four books and hundreds of newspaper and magazine articles and short stories. While he wrote nothing of consurnmate literary merit, he made noteworthy contributions in the area of conservation before it was fashionable and in the areas of western history and literature when the West was considered a subject fit only for dime novels and pulp fiction.

As a working journalist, Hough traveled over the American West in the closing decades of the nineteenth century when the West was being transformed from a wilderness into a civilized region. He participated in that change inasmuch as his writing contributed to the integration of the West into the national identity. Like his friend Theodore Roosevelt, Hough developed into an historian of the westward expansion and an ardent patriot who saw in the western experience the traditional American ideals of individuality, courage, strength, and pragmatic integrity he felt were necessary for the survival of modern

1 Saturday Review of Literature, 18 (July 30, 1938), pp. 3-4.

2 Ibid., p. 4.

3 See Delbert E. Wylder, "Emerson Hough's 'Heart's Desire," Western American Literature, 1 (Spring, 1966), pp. 44-54; Delbert E. Wylder, Emerson Hough (Austin, Texas: Steck-Vaughn Company, 1969). 
America. As a writer of western history and fiction, Hough sought to establish the West as a subject with enough dignity and interest to transcend the popular image of the Wild West cultivated by writers ignorant of the true West or its past. As a conservationist and an authoritative commentator on every sport from fly casting to bear hunting, he sought to preserve the American wilderness because he saw it as a source of the nation's strength and uniqueness. His most popular novels, The Covered Wagon (1922) and North of 36 (1923), were the culmination of his efforts to identify the West with the ideals of the American past.

Though a midwesterner, Hough was a product of the frontier tradition. He was born in Newton, Iowa, on June 28, 1857. His parents, Joseph Bond Hough and Elizabeth Hough, had emigrated from Virginia to Jasper County, Iowa, in 1852. John, the first Hough to reach the American colonies, had emigrated from Chester, England, in 1683, and his descendants subsequently moved from Pennsylvania to Loudoun County, Virginia. Emerson Hough was always proud of his southern, Anglo-Saxon ancestry because it testified to his "ancient, undeniable one hundred percent Americanism."4 Joseph Hough taught school, served as a county clerk, worked as a county surveyor and a farmer, and at one time was a grain and lumber merchant. ${ }^{5}$ Emerson Hough himself displayed the same kind of frontier versatility in his lifetime. In fact, his father was the prototype for many of his fictional heroes and a pattern for his own life. "My father was a Virginian," Hough said once, "a grand man as I look at it, simple, temperate, manly, the best shot with rifle or gun that I ever saw. I suppose I got my love of field sports and my love of the Old West from him-that it was heredity that sent me west and shaped much of my later course of life."6 Hough was a proficient sportsman himself, hunting and fishing in every state of the Union and in Canada and Mexico before he died. He maintained a husky appearance and led a strenuous life in spite of constant illnesses which plagued him from childhood. Fortunately, this enforced idleness as a child allowed him to read a great deal. He indulged his preference for romanticism in Tennyson's Idylls of the King; and the battle scenes in the Biblical Book of Kings provided a natural transition to Ivanhoe and most of Walter Scott's historical fic-

\footnotetext{
4 Edwin Hunt Hoover, "Emerson Hough on Writing," The Student Writer, 7 (December, 1922 ), p. 8.

5 [Emerson Hough] Getting a Wrong Start (New York: The Macmillan Co., 1915 ), p. 13. This autobiography was published anonymously.

6 Publicity material from the Bobbs-Merrill Collection, Manuscripts Department, Lilly Library, Indiana University, Bloomington, Indiana. Subsequent references will be cited Bobbs-Merrill Collection.
} 
tion. ${ }^{7}$ Perhaps the book which influenced Hough most was Henry Howe's Historical Collections of the Great West, published in Cincinnati in 1851. "I still think this is one of the great books of America," he said, "for it showed us America as it once was-the most wonderful country ever occupied by civilization. I wish those old days were back, or that I had been born in them."8 As a youth, Hough was deeply impressed by Howe's declaration in the preface of his book that historical fiction had greater charm than plain history.

Hough graduated with two other pupils from the local high school at Newton, Iowa, in 1875, and after teaching in a country school for one term, he entered The University of Iowa in 1876. His university career was an eventful one in which he played on the football team, edited the college newspaper, and graduated Phi Beta Kappa in 1880. Hough's father urged his son to study law, partly out of his own failure in that ambition for himself; but reluctant to enter the legal profession, Hough spent some time as a surveyor in a civil engineering party before deciding to read law. As a diversion from his studies he began to write sketches on the outdoors and on hunting for publication in eastern magazines. His first published article, "Far From the Madding Crowd," which appeared in Forest and Stream (August 17, 1882), revealed a romantic primitivism which was to pervade his later work: "There is no more natural or effective way to rest," he wrote, "than to merge for a time the artificial man into the natural; to sink civilized training in the instincts given us by our fathers, the savages ..."

Hough was admitted to the bar in 1882 at Newton, Iowa. Shortly thereafter, an unhappy love affair precipitated a desire to travel west. Fortunately a friend who was practicing law in White Oaks, New Mexico, invited him to join his law firm there, and when the American Field offered him a free railroad pass to write some sketches on the Southwest for them, Hough left immediately for New Mexico.

The New Mexico Territory in the 1880's was a place of social and political upheaval, the scene of murders, range wars, Indian uprisings, and the coming of the railroad-the last frontier. Hough arrived in White Oaks on June 1, 1883, and formed a law partnership with Eli $\mathrm{H}$. Chandler. At this time White Oaks-"half mining camp and half cow camp"-was considerably tamer than its neighbors, Lincoln and Fort Stanton, which were just recovering from the ravages of the Lincoln County War and the tempestuous career of the late outlaw, Billy the Kid. But, despite the inevitably numerous legal proceedings typical of

7 Letter from Emerson Hough to George Leon Varney, August 24, 1911, Hough Collection, Iowa State Department of History and Archives, Des Moines, Iowa. Subsequent references will be cited ISDHA.

8 Letter from Emerson Hough to Emilie B. Stapp, November 20, 1911, ISDHA. 

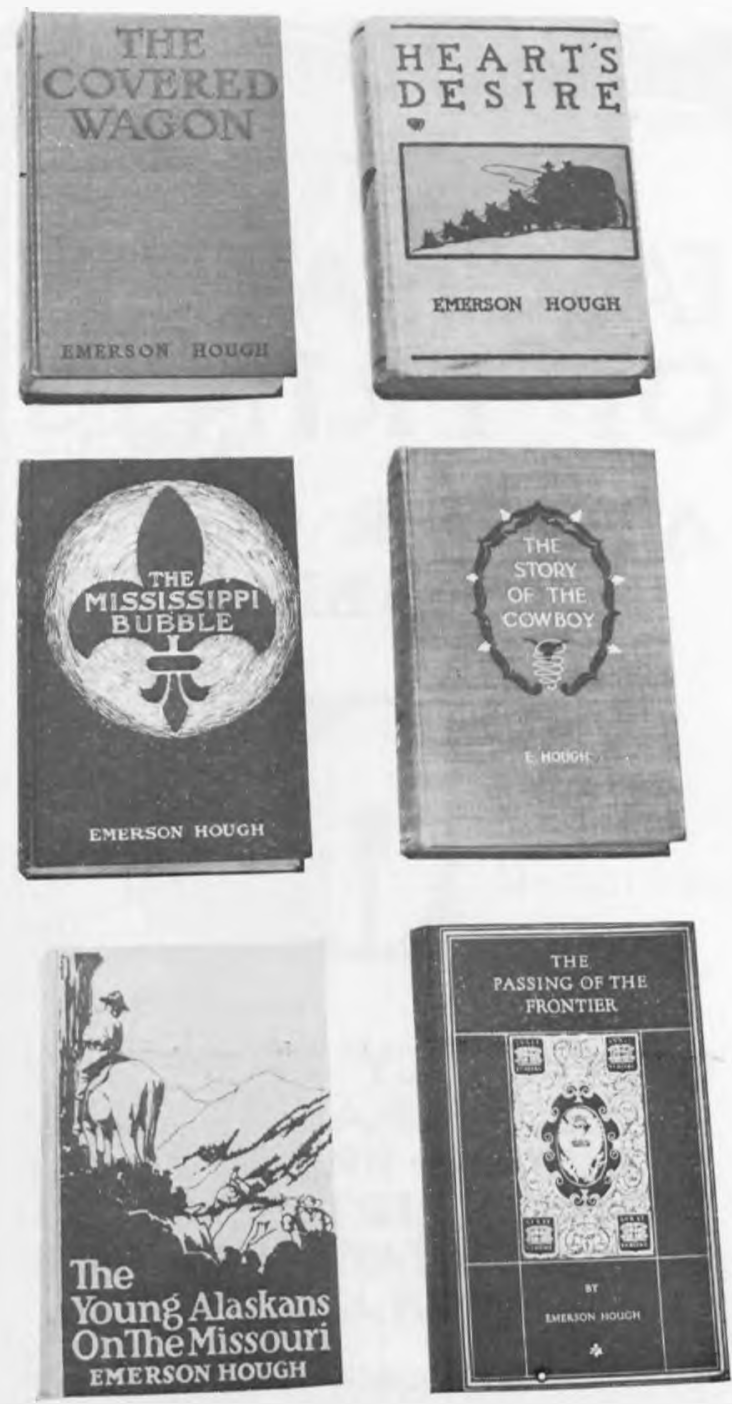

Emerson Hough was the author of more than thirty-four books. His six volumes shown above. from the Iowa Authors Collection, are mentioned particularly in Carole M. Johnson's essay in this issue. 
a mining community, Hough and his partner did not have much of a law practice. ${ }^{9}$ Increasingly, Hough was more attracted to the pleasures of the hunt than to the drudgeries of the law, and he later admitted that he devoted a great deal of time to bear hunting. Recognizing that a man had to be versatile in order to survive, Hough spent the remainder of his time working as a reporter and sometime editor on the Golden Era, a weekly White Oaks newspaper. Eventually, journalism began to occupy as much of his time as hunting.

During his stay in New Mexico, Hough had been gathering material for the American Field and other midwestern publications like Field and Stream and Outing. In a series of sketches which appeared in the American Field from June 2, 1883, to May 31, 1884, he wrote about his travels in the Southwest. These sketches reveal a perceptive response to an environment that must have appeared strange if not extraordinary to the young man from the Midwest. This response often takes a humorous and, in some cases, comic form, foreshadowing some of his best work in Heart's Desire. Other more serious sketches show a remarkable insight into the powerful influence of the frontier environment upon its inhabitants, at its worst twisting the soul with loneliness, at its best eliciting superior qualities of courage, self-reliance, individuality, and pragmatic integrity that were necessary for survival in the West. "The ancient law of individualism and of the survival of those who ought to survive, was the actual law of the land," Hough wrote of the West he had known in the 1880's, and he firmly believed and advocated the idea that "environment produced the creature." 10 To a great extent Hough's life in White Oaks determined the kind of values he admired, but his attachment to White Oaks was based on more than a youthful romanticism. While he was frankly idealistic about the place, he also recognized that White Oaks, as he had known it, had been real, and he was concerned with capturing that reality before it vanished into unrecognizable myth: "One saw there the actual old West, not the railroad tourist West, but the real West, with its population made up of flotsam and jetsam of the westbound tide of humanity." 11 Consequently, in his best western fiction, Hough based his stories on his own personal observations and experiences, showing little tendency to romanticize or exaggerate his characters or the West.

9 Their one important case, a litigation involving a gold mining claim, was decided against them on May 3, 1884. See William A. Keleher, The Fabulous Frontier (Santa Fe: Rydal Press, 1945), pp. 32 and 134.

10 Emerson Hough, The Sowing (Chicago: Vanderhoof-Gunn Co., Ltd., 1909), p. 143.

11 Emerson Hough, "Chicago and the West," Field and Stream (June, 1904). p. 183. 
In February, 1884, Hough returned to Iowa to attend his mother, who was ill. When he found his father in serious financial difficulties, he abandoned the law altogether and turned to journalism to support his family. From February to October of 1884, he worked as the business manager of the Des Moines Times, and in late November of that year he became the associate editor of the Register in Sandusky, Ohio. Hough also wrote humorous stories for the McClure-Phillips syndicate at five dollars a column and articles on sports for the St. Louis GlobeDemocrat at six dollars a column. From Sandusky, Ohio, he went in 1889 to Chicago, where he worked on the American Field, the sporting publication to which he had previously contributed. His assignments for this magazine took him to Colorado, Wyoming, Nebraska, Kansas, New Mexico, the Indian Nations, Texas, and other wild, remote parts of the country. He later recalled that by age thirty-two he had been successively "a sewer of grain sacks, a rodman, a levelman, a law student, a lawyer, an editor, a reporter, a solicitor, a collector of bad debts, a special writer, a townsite boomer, and a newspaper owner."12 Since 1882 he had contributed occasional sketches on hunting and fishing to Forest and Stream, a New York sporting journal, and in 1889 he became its western representative. His responsibility was to edit the "Chicago and the West" column for fifteen dollars a week. His job also required him to solicit advertising, an activity he disliked intensely. Nevertheless he resolved to become "the best posted man in America engaged in the journalism of outdoor sports." 13 Of the years between 1889 and 1904 he later wrote: "I never worked harder in my life than I did at this time, and I don't know that I have ever been happier. In all this time I was getting a sort of education which embraced pretty much all of western America. I knew western standards and western life pretty well."14

One of Hough's trips during this period had far-reaching effects. In the winter of 1893, in company with his friend and guide Billy Hofer and two soldiers from Fort Yellowstone, Hough crossed the whole of Yellowstone National Park in below-zero temperatures for the purpose of photographing the wild game and counting the buffalo, whose number was dwindling because of the encroachment of winter poachers. Though the authorities thought there were five hundred buffalo left in the park, Hough could hardly find one hundred. In the course of his trip he was also instrumental in capturing a poacher. When the army fined the poacher only by confiscating his outfit, Hough was outraged

12 Getting a Wrong Start, p. 125.

13 Ibid., p. 140.

14 Ibid., pp. 140-141. 
and wrote a report showing the absurdity of the park regulations as practical protection for the wildlife and emphasizing also the actual extent of the ravages of the poachers on the park buffalo. This report, later published in an eastern newspaper, moved Congress in May, 1894, to pass a strong law making the poaching of wild game in the park a punishable offense, the first time that government protection had ever been given to the buffalo. Hough said of his part in this historic event: "I have always thought this was about as useful a thing as I ever was able to do in the somewhat thankless attempt to be of service to the wildlife of America."15

By 1897 Hough had reached middle age without notable professional success. Marriage to Charlotte Cheesebro in that year brought stability into his life and gave a direction to his career. In order to increase his income he began utilizing the accumulated experience of years of travel and observation-what he called his "vacation work"by writing about what he knew best. In 1896, through the influence of George Bird Grinnell, owner of Forest and Stream, Hough was asked to do a volume on the cowboy for the "History of the West" series, edited by Ripley Hitchcock. The Story of the Cowboy (1897), a historical and factual treatment of the cowboy and his life which is still considered a classic document on the cattle industry, established Hough's reputation as a western writer. ${ }^{16}$ Critical reception of the book was almost unanimously favorable and even enthusiastic, and the praise of people like Hamlin Garland and Theodore Roosevelt encouraged Hough tremendously. Garland wrote to Hough, saying that "It is a splendid performance. It has the power of the larger sort. It has dignity, restraint and structure. I wish I had written it myself."17 Theodore Roosevelt's approval meant even more to Hough; he marked this year as his true arrival as a western writer and Roosevelt's congratulatory letter as a landmark and inspiration in his life:

I don't know when I have read a book that I like more than your "Story of the Cowboy." I have always been hoping against hope that such a book would be written, but I had about given it up, and there was scant time remaining in which anyone could write it. At last, thank Heaven, it has been done! Not only is it to my

15 Emerson Hough, "Made in America," Saturday Evening Post, 187 (June 5, 1915), p. 57.

16 Some adverse criticism of Hough's book, in particular his treatment of Billy the Kid, is given in Ramon F. Adams, Six-Guns \& Saddle Leather (Norman: University of Oklahoma Press, 1954), pp. 186-187.

17 Letter from Hamlin Garland to Emerson Hough, October 2, 1897, ISDHA. 
mind a most fascinating book, but I think it is as valuable a bit of genuine contemporary history as I have yet examined. ${ }^{18}$

Though The Story of the Cowboy did not make much money, Hough was encouraged to complete his next book (a novel this time) within a few months, working on it at night and pursuing his journalistic activities during the day. When it was published in 1900, The Girl at the Halfway House attracted little attention and made even less money. Though not an artistically successful novel, The Girl dealt thoughtfully and intelligently with the problems of the settlement of the West, focusing specifically on the development of a Kansas cow town into a prosperous, civilized city. In fact, this novel and the short stories Hough wrote during this period show an artistic and intellectual growth, and their success is based mainly on his objectivity and honesty in dealing with western themes.

Hough's next novel, The Mississippi Bubble, published by the BobbsMerrill Company in 1902, was a huge popular success. He had based it on an incident in Henry Howe's Historical Collections of the Great West, and although the novel was set in Europe, "the life of it was the idea of the New World and the American West."19 Hough had written the Bubble as he had his previous novel, between 10 p.m. and 4 a.m. after a full working day at the Chicago office of Forest and Stream. He was at the same time supplementing his thirty-dollars-a-week salary with newspaper work and articles on conservation and the outdoors. He was also forty-five years old and a self-proclaimed failure. Consequently the success of this novel astounded and delighted him. It was fourth on the bestseller list of 1902 and earned him $\$ 11,640.15 .{ }^{20}$

In 1902, the same year that he signed with Bobbs-Merrill for the first time, Hough published his first "Curly" story in the Saturday Evening Post. ${ }^{21}$ The "Curly" stories, a series of humorous western tales that appeared in the Post from 1902 to 1905, constitute the best fiction that Hough ever wrote. The setting for all these stories, a place called Heart's Desire, was actually the small southwestern town of White Oaks, New Mexico. Though Curly, an irrepressible, fun-loving cowboy, ap-

18 Letter from Theodore Roosevelt to Emerson Hough, September 30, 1897, ISDHA. This letter was published in Annals of Iowa (October, 1925), p. 151.

19 Publicity material, Bobbs-Merrill Collection.

20 Ibid.

21 Thereafter, until his death, his fiction and historical and conservation pieces appeared with regularity in the Post. The endurance of this association was owing in great part to Hough's relationship with the Post's editor, George Horace Lorimer, for whom he had the greatest respect and friendship. Both men shared a passionate love for the Far West and an intense zeal for conservation; both were avid antique collectors, fishermen, and hunters. 
pears at times as the narrator and at others as the subject, it is clear that he represents the western point of view. ${ }^{22}$ In these stories Hough investigated through humor and satire the meaning of western life within the context of modern American culture. The flexibility of short fiction stimulated his real talent for comedy, burlesque, and dialogue, which is reflected in the spontaneity, charm, and genuine literary merit of these tales. Hough received an enthusiastic response from the readers of these tales, especially from Eugene Manlove Rhodes, a New Mexican who wrote a congratulatory letter to thank him for the realistic portrayal of "a much maligned people." 23 Rhodes also encouraged him to put these stories into book form, which Hough did despite a serious bout with typhoid fever in the spring and summer of 1905 . The resulting novel, Heart's Desire, was for the most part a successful work and by far Hough's best novel. It was carefully constructed and it raised some serious issues concerning the settlement of the West and American frontier experience. The book was nevertheless a dismal failure financially. The royalties did not even pay the advances Hough had received under the terms of the contract. Though his publishers placated him by suggesting that the book was simply "too good for success as a popular story," Hough was bitterly disappointed because he had sincerely believed in the artistic merit of the novel.

The failure of Heart's Desire and The Story of the Outlaw (Hough's version of the Lincoln County War published in 1907) convinced him that there was no financial value in his western work. However, he continued to publish articles on conservation and the West in many periodicals, becoming eventually a spokesman and apologist for the West against eastern critics. ${ }^{24}$ In 1908 he began to write a weekly column on outdoor topics in the Post, entitled "In the Open." He told Lorimer that instead of discussing polo, football, or baseball, he would argue for preserving such nature as was left and eliminating waste of the natural resources. ${ }^{25} \mathrm{He}$ believed that the Post could do more than the sporting papers were able to do, and through this column and his

22 It seems that Hough was attempting to dispel the popular stereotype of the cowboy engendered by Wild West writers: "I must confess that I found the class cow puncher to embrace a wide variety of individuals, not all of whom dressed alike, acted alike, or sang alike. I know this is an idea different from the Eastern one regarding cow punchers which seems to be that they are bred true to a very singular type." (Letter from Emerson Hough to Arthur Farwell. August 21, 1908. ISDHA.)

23 Letter from Eugene Manlove Rhodes to Emerson Hough. April 18, 1905. ISDHA.

24 The most significant statement he made about western literature appeared in an article, "Wild West Faking," in Collier's (December 19, 1908), pp. 18. 19. and 22.

25 Letter from Emerson Hough to George H. Lorimer, April 29. 1908, ISDHA. 
other articles, the Post became a very effective news organ for the conservation movement, with Hough as one of its strongest and most visible proponents.

Not until the publication of The Covered Wagon in 1922 did Hough enjoy again the success of his first bestseller, The Mississippi Bubble. ${ }^{26}$ Nevertheless in the intervening years his writing afforded him a comfortable living. He enjoyed his career despite the constant pressurc to produce a steady stream of marketable material, most of which he gathered on his summer trips. Hough responded to these demands with incredible stamina and ingenuity, in some cases using the same material in different ways. For example, a financially disastrous investment in farming by irrigation in Texas became the basis for an amusing and informative article, "Under the Ditch in Texas," which appeared in Outing (February, 1909).27 In another instance, Hough satirized the land frauds he had discovered taking place in the West through a series of Curly stories which appeared from 1909-1913 in the Post, Collier's, and the Popular Monthly. Unable to editorialize on these land abuses for fear of offending the editors of the Post, who were closely allied with big business, Hough wrote these stories out of a sense of indignation, and incidentally produced some of his better fiction.

Hough's inability to make money on his western fiction continued to discourage him considerably, and after 1913 he produced a large number of articles, short stories, and books on more topical, modern concerns. Most of his important work was done in conservation. These articles were often reprinted by conservation clubs and did much to promote the movement nationwide. Hough also wrote "The Young Alaskans" series of books for young people, encouraging them to enjoy outdoor life and preserve the natural environment. In fact, Hough was so active in the conservation of the national parks that on different oc-

26 Between 1909 and 1912 Hough published three novels dealing with politics. Hough's lack of faith in politicians was the major reason for his insistence that American citizens should be exposed to the history and political theories of their country so that they could judge their government and politicians intelligently. 54-40 or Fight (1909) had as its chief character John Calhoun and as its chief concern the political intrigues surrounding the acquisition of Texas and the Northwest Territory. The Purchase Price (1910) was concerned with the adventures of a mysterious Hungarian countess, an abolitionist, whose occupation was stealing slaves in pre-Civil War America and setting them at liberty. John Rawn (1912), the third novel, tells the story of a corrupt Chicago financier of 1912 and his attempt to monopolize the power sources of the United States. 54-40 or Fight was moderately successful, but the other two novels were critical and financial failures.

27 The University of Iowa Library has an interesting collection of forty-nine letters from Emerson Hough to Mr. Conrad Goeth of San Antonio, Texas, spanning the years 1903-1912, which document this ranching adventure. 
casions he was offered the position of superintendent of Yellowstone Park and Grand Canyon Park. He turned down the offers because the salary was too low, but he admitted privately that an official position, especially a government post, would restrict his freedom. ${ }^{28}$ Nevertheless, he did not lose his passion for western history, and in 1917 he eagerly accepted an invitation to write a volume on western subjects for the "Chronicles of America" series, a cooperative history in fifty volumes, edited by Allen Johnson for the Yale University Press. The general editorial scheme was to relate American history in terms of "a romantic adventure of epic proportions." Hough's contribution, The Passing of the Frontier: A Chronicle of the Old West (1918), fit this requirement exactly because it was a compilation of his sketches and articles from previous years. He did not attempt to discuss the influence of the frontier on American politics as he had done in his earlier historical accounts. Instead, he included chapters on the more striking phases of frontier life in the Far West in its mid-century stage of existence. In an about-face from his provious views in The Story of the Cowboy and The Story of the Outlaw, in which he had glorified the individual hero, he reserved his highest praise in The Passing of the Frontier for the settlers:

The chief figure of the American West, figure of the ages, is not the longhaired, fringed-legging man riding a raw-boned pony, but the gaunt and sad-faced woman, following her lord where he might lead, her face hidden in the same ragged sunbonnet which had crossed the Appalachians and the Missouri long before. That was America, my brethren! There was the seed of America's wealth. There was the great romance of all America-the woman in the sunbonnet; and not, after all, the hero with the rifle across his saddle horn.

The research he had done for The Passing of the Frontier became the basis for a series of articles on western themes that Hough wrote for the Post in 1919, "Traveling the Old Trails." A few of the subjects Hough dealt with were the pioneer migration of the 1840 's, the early exploration of the Far West and the Northwest by Lewis and Clark, and the cattle industry, the subjects of his earlier and more successful work. These articles were marked by an extreme patriotism and individualism, a personal reaction to what he considered the socialist threat to the American political system. Indeed, this resurgence of interest in

28 Letter from Emerson Hough to George H. Lorimer, December 2, 1918, ISDHA. 
the national heritage of older, simpler values was symptomatic of his general bewilderment at the social upheavals, the complex international politics, and the changing social mores of the postwar period. In a series of letters he wrote to his friend Frederick Bigelow, Hough expressed these feelings. In 1921 he wrote: "I'm afraid I belong to an earlier age ... when I see the jazz life of these hysterical tourists bent on pleasure and hurry, I like that not even so well. I reckon there is no place for me." ${ }^{29}$ In a letter which revealed the source of his nostalgia, Hough wrote of his disgust with the current administration, the government, and the country in general, and he added wistfully: "If I knew of any place in the world like White Oaks, New Mexico, as it was in 1880 I should take the next train thither."30

The Covered Wagon (1922) was written in this mood, and it was an immediate and spectacular success. Most reviewers praised the book, not for its literary merit, which they readily acknowledged as negligible, but for its description of an event of great intercst and importance, the pioneer migration of the 1840 's. The appeal of the novel lay in Hough's graphic visualization of the pioneer advance in the West and the purpose and courage of the dauntless pioneers, suffering great danger and privation to achieve their goal. This representation of the past was met with great approval by the public because it affirmed the sanctity of older values and offered hope that these values would prevail again. The nostalgic awareness of The West That Was, which dominated The Passing of the Frontier, was present in The Covered Wagon and to a certain extent determined its success. Similarly, when the motion picture based on Hough's book was made, its patriotic appeal was probably as much responsible for its huge commercial success as its spectacular elements. It ran fifty-nine wecks at the Criterion Theater in New York City, eclipsing the record of The Birth of a Nation. The film's "thrilling interpretation of the pionecr spirit that made America" impressed one reviewer particularly. His observation that "boys and girls will get from its two hours a vivid and lasting impression of the history of their country that would generally be too much to hope for from months of conventional study" is evidence that Hough's desire to teach Americans a proper version of their own history was fulfilled. ${ }^{31}$ In much the same vein Robert E. Sherwood gave Hough this tribute: "He had the ultimate satisfaction of

29 Letter from Emerson Hough to Frederick Bigelow, August 2, 1921, The University of Iowa.

30 Letter from Emerson Hough to Frederick Bigelow, June 8, 1920, The University of Iowa.

31 " "The Covered Wagon,' Epic of the Oregon Trail," American Review of Reviews, 67 (June, 1923), p. 645. 
knowing that he had honestly reflected a period in American history of which every American has a right to be proud." 32

What The Covered Wagon had done for the romantic pioneer days of the 1840's, North of 36 (1923) did on the same sweeping scale for the cattle trail days of the 1870 's. Hough began working on the new novel even before the publication of the Wagon. Although persistent illness plagued him, he characteristically refused to slow down. While vacationing in Colorado in early July, 1922, he became gravely ill and had to be hospitalized. Thinking he would not live long enough to finish his novel, Hough called his friend Andy Adams, explained to him his outline for the book, and asked him to finish it. Nevertheless, Hough recovered enough to return to Chicago by December, 1922 . with an almost completed manuscript. He sold the serial rights to the Post for fifteen thousand dollars, and in February, 1923, he sold the picture rights for the spectacular sum of thirty thousand dollars. ${ }^{33}$ Hough was never able to enjoy this success. Having achieved at last the financial security he had worked so long and hard to get, he died on April 30, 1923, just a week after he had attended the Chicago premier of The Covered Wagon.

It is fitting that North of 36 was his last novel. ${ }^{34}$ Concerned with the beginning of the great cattle drives from Texas northward in the Reconstruction days, the whole novel focuses on the cattle trail, which Hough saw uniting North and South and creating the "first and only true American tradition-the tradition of the West." 35 Though North of 36 had little literary merit, Hough had created a regional novel that was for the most part faithful to the customs and practices of the Texas cattle country. He had realized the main objective of his career in western writing-to identify the tradition of the West with the American tradition.

The Covered Wagon and North of 36 were the culmination of Hough's lifelong ambition to integrate the West into the national identity. Though his historical fiction was often marred by a tendency toward didacticism and an adherence to a rigid romantic formula, he reaffirmed the values of a past that were threatened at a time of social and political upheaval. Moreover, in all phases of his writing he be-

32 Robert F. Sherwood, Best Moving Pictures of 1922-23 (Boston: Small, Maynard, 1923), p. 77.

33 Letter from Emerson Hough to W. D. H. Koerner, February 20, 1923, courtesy of Ruth Koerner Oliver.

34 There were two novels published posthumously, Mother of Gold (1924) and Ship of Souls (1925), but they are undistinguished and little read. 308.

35 Emerson Hough, North of 36 (New York: D. Appleton and Co., 1923), p. 
queathed a vision of America defined in terms of the western experience, and he made this vision a part of the national heritage. 